\title{
Content Analysis of Organic Food Claims on Websites and Instagram Stores
}

\author{
Miranti Alfiah Saraswati ${ }^{*}$, Ujang Sumarwan ${ }^{2}$ \\ ${ }^{1,2}$ Department of Family and Consumer Sciences, Faculty of Human Ecology, \\ IPB University, Bogor 16680, Indonesia \\ *Corresponding author: miranti_alfiah@apps.ipb.ac.id
}

\begin{abstract}
Organic food products are produced without pesticides or genetic engineering. This study analyses the variable product characteristics, website characteristics, Instagram account characteristics, and claims characteristics. This study aimed to analyze the content of claims for organic food on websites and Instagram stores based on the Consumer Protection Law No. 8 of 1999. This study used an exploratory design with content analysis methods. The sample was selected using purposive sampling, namely 100 online shops that sell organic food with details of 50 websites and 50 Instagram accounts. The data collected was categorized and processed using Microsoft Excel, Statistical Package for Social Science (SPSS) 23.0 and Nvivo 12 Plus. The analysis results show that $56 \%$ of website and Instagram stores use subjective claims and $40 \%$ using objective claims. As much as $47 \%$ of online stores, both websites and Instagram, are categorized as not misleading, and 53\% are categorized as misleading or deceptive claims such as ambiguous. $22 \%$ of online shops violate Article 8 Paragraph 1, and $20 \%$ of online stores violate Article 9 of the Consumer Protection Law.
\end{abstract}

Keywords: claim, content analysis, instagram, organic food, website

\begin{abstract}
Abstrak
Produk makanan organik diproduksi tanpa pestisida maupun rekayasa genetika. Penelitian ini menganalisis variabel karakteristik produk, karakteristik website, karakteristik akun Instagram, dan karakteristik klaim. Tujuan penelitian ini untuk menganalisis isi klaim makanan organik pada toko website dan Instagram berdasarkan Undang-Undang Perlindungan Konsumen No 8 Tahun 1999. Penelitian ini menggunakan desain eksploratif dengan metode analisis isi (content analysis). Sampel dipilih menggunakan purposive sampling yaitu 100 toko online yang menjual makanan organik dengan rincian 50 website dan 50 akun Instagram. Data yang dikumpulkan dikategorikan dan diolah menggunakan Microsoft Excel, Statistical Package for Social Science (SPSS) 23.0 dan Nvivo 12 Plus. Hasil analisis menunjukkan bahwa 56 persen toko website dan Instagram menggunakan klaim subjektif dan 40 persen menggunakan klaim objektif. Sebesar 47 persen toko online baik website ataupun Instagram termasuk kategori tidak menyesatkan dan 53 persen termasuk kategori klaim yang menyesatkan atau menipu seperti ambigu. Terdapat 22 persen toko online yang melanggar pasal 8 Ayat 1 dan 20 persen toko online yang melanggar pasal 9 Undang-Undang Perlindungan Konsumen.
\end{abstract}

Kata kunci: analisis isi, instagram, klaim, makanan organik, website 


\section{Introduction}

In Indonesia, organic farming is becoming a trend due to growing consumer awareness to consume safe and healthy products (Windani, Kikik \& Awaliyah, 2020). During the Covid-19 pandemic, the importance of maintaining immunity is also intensified to the community. One way to maintain immunity is to eat healthy and nutritious food. The growth of a healthy lifestyle in the community increases the demand and intention to buy organic food (Qi, Yu \& Ploeger, 2020). According to the Minister of Agriculture Regulation Number 64/Permentan/Ot.140/5/2013, organic is a labelling term that states that a product has been produced according to organic production standards and is certified by an official certification agency.

According to a statistical data survey of organic agriculture (Institute, Alifa \& Kombas, 2020), consumers bought organic products through social media or online stores and via platforms by $21.21 \%$ during the pandemic. Currently, many organic products, one of which is food, are sold through online store websites. A website is an internet or mobile application and can search for the desired product for business transactions (Ichsan, Jumhur, Hum \& Dharmoputra, 2018). Organic food is sometimes more expensive than conventional food due to the high cost of organic certification. Organic products can be claimed organic by organic sellers and facilitators. Even though they have claimed the product is organic, the seller must provide access to the consumer to visit the farmer so that there is confidence and trust that the product has been processed organically. However, when the distance between consumers and farmers is far and only limited online, it is necessary to guarantee a certificate from the authorized institution to feel confident in the organic product (Novita, 2017). In addition to websites, currently, online business is mostly done on Instagram because apart from being a social media for sharing videos and photos, Instagram can be used as marketing. To facilitate purchases, business actors provide contact information that can be contacted by consumers who want to buy or inquire about uploaded products (Wulandari \& Husna, 2016). Therefore, the information displayed on Instagram accounts is very useful for consumers.

Claims are all forms of descriptions that state-specific characteristics of food with regard to origin, nutritional content, properties, production, processing, composition or other quality factors (National Agency of Drug and Food Control, 2017). In general, nutritional claims and health claims can be found on organic food products, and these claims must be seen following the nutritional evidence available in these foods (Kahl et al., 2010). Additional labeling or information on organic food claims can increase purchases. Health claims most influence consumers to buy organic food (Cagalj, Haas \& Morawetz, 2016). Therefore, health-related food product claims are increasingly being used. With information about product benefits, health claims can provide added value for consumers. To assess a claim, consumers must first process the information, understand the contents of the claim, and finally decide whether the benefits are good or not for themselves (Lahteenmaki, 2013). According to Sumarwan (2011), many manufacturers still do not provide facts for consumers, and some producers still use deceptive and misleading claims and product claims that do not match the actual situation. Several rules regulate business actors' claims and advertisements in Law Number 8 of 1999 concerning Consumer Protection, such as articles 8 and 9. The rules in the UUPK have stated clearly, but some business actors have not responded seriously (Laila, 2017). The purpose of this research are 1) identify the characteristics of organic 
food products on websites and Instagram; 2) identify the characteristics of online stores, websites and Instagram that sell organic food products; 3) analyzing the content of organic food product claims on the website and Instagram; 4) analyzing organic food product online stores based on the Consumer Protection Act No. 8 of 1999.

\section{Literature Review}

\section{Organic Food}

According to the Regulation of the Minister of Agriculture Number 64/Permentan/Ot.140/5/2013 Organic products is produced according to organic food system standards, including organic processed food raw materials, organic, supporting materials, plants and fresh plant products, livestock and livestock products (including non-food). Organic products emphasize claims to the process rather than claims to the product. Therefore to monitor the product is truly organic, it is necessary to have institutions that supervise, foster and regulate it (Mayrowani, 2012). Indonesia's main organic agricultural products are rice, fruit, vegetables, cocoa, coffee, cashew, coconut oil, herbs, honey, and spices. Among these products, vegetables and rice are the most produced by farmers (Mayrowani, 2012). Organic products circulating in Indonesia and already having an organic certificate must add a logo that says "Organik Indonesia" on their products. Organic product certification guarantees that the product is organic and easier to sell domestically and abroad (Wibowo \& Husnain, 2015).

\section{E-commerce Website as Sales Media}

The use of the website can be used to create a profile of a company, individual, organization, trade-in e-commerce, and used as a website for humanity (Pudjiarti, Nurlaela \& Sulistyani, 2019). Websites or e-commerce sell products to consumers online. Trading through the website is a form of market and technological change that significantly impacts businesses, including consumers, producers, and related stakeholders (Sumarwan, Noviandi \& Kirbrandoko, 2013).

E-commerce provides benefits for consumers by providing information about products, facilitating price comparisons, offering delivery convenience, and offering consumers buying easy because it is only through a computer or mobile device and can be done anywhere at any time. Moreover, online purchasing platforms can help reduce the panic hoarding of food. Besides that, online platforms provide a convenient shopping place to eliminate the risk of consumers interacting with other visitors during a pandemic. Thus, e-commerce businesses are highly praised for their contribution to food distribution (Hao, Wang \& Zhou, 2020).

\section{Instagram}

Instagram is an application that is used to share photos or videos that can be seen by followers of the photo or uploader and is an application that can provide comments to other Instagram users. The Instagram application requires an internet connection to access it (Kertamukti, Ilmu, Uin \& Kalijaga, 2015). Apart from being used for photography and video, Instagram creates an online business and markets a product to make it more widely known. This can be done by anyone and anywhere because they 
only have gadgets and smartphones. The features available on Instagram can make products look attractive and simple. Products sold can use hashtags (\#) to make it easier for potential buyers to find the products they want (Fitria, 2015).

\section{Claim}

According to Sumarwan (2011), the nature of claims is divided into 4, namely objective, subjective, irrational, and two-meaning claims. Objective claims can be proven true, subjective claims are difficult to measure because they are only the seller's statement, irrational claims are claims that are not supported by logic, and two-meaning claims are partially true and partially true false claims. Organic claims must meet organic standards from seedling to harvesting. Organic food with organic seeds is not recognized if the planting process uses non-organic fertilizers (Wijaya, 2017). Therefore, it is necessary to form an organic certification agency that plays a role in maintaining the validity of organic products, for example involving universities in organic certification efforts. Claims about organic products are a concern for consumers. According to (2017), claims are all forms of descriptions that state, suggest or indirectly state-certain characteristics of food concerning the origin, nutritional content, properties, production, processing, composition or other quality factors. According to Article 17 UUPK Misleading claims deceive consumers, describe information incorrectly, provide an incomplete picture, and provide excessive information.

\section{Consumer Behaviour towards Purchase of Organic Food}

Consumer behaviour is an activity that includes actions before buying goods or services, when buying, using, spending, and evaluating the goods or services purchased. Consumer behaviour is used to understand why consumers do this (Sumarwan, 2011). According to research by Fauzi and Yuliawati (2020), Consumer behaviour in buying organic vegetables is influenced by consumer satisfaction. This is indicated by satisfied and happy consumers who will sustainably buy organic vegetables and share their experiences with others. Organic food can increase endurance and is considered more nutritious than conventional food. The level of consumer perception of health is high when buying organic food (Waskito, Ananto \& Reza, 2014). However, consumer perceptions of the price of an organic and environmentally friendly product are different. Price irregularities will affect the desire or intention of consumers to buy a product (Kurniawan, 2020). Research Burton, Lichtenstein, Netemeyer and Garretson (1998) said that price perception relates to consumer behaviour towards brands. Perceived price will drive behaviour towards the brand and lead to purchase.

\section{Content Analysis}

Content analysis is a research method that does not use humans as research objects but uses symbols or texts in certain media to be processed and analyzed. The steps taken to carry out content analysis are formulating problems, conducting literature studies, determining units to be observed and analyzed, determining samples, determining variables, making coding categorizations, collecting data, coding data, processing data, presenting data, providing interpretation, and compiling research reports (Martono, 2011). Content analysis studies and concludes a phenomenon by 
utilizing documents. Content analysis can be used to understand attitudes, community views, and changes in society obtained from documents (Eriyanto, 2011).

Content analysis is a research technique to conclude a text or other. Content analysis can provide new insights to improve researchers' understanding of certain phenomena. Content analysis is not only an analysis of text but other objects such as pictures, signs, sounds, and numerical notes on a person's statement about a perceived phenomenon (Krippendorff, 2018). According to (Ahmad, 2018), qualitative content analysis is a researcher's effort to construct reality and understand its meaning. This study is very concerned about the process, authenticity, and events. Content analysis research related to verbal data must mention the date, place, and communication tools used. However, if the object of research is related to the message in the media, it is necessary to identify the message and the media that conveys the message.

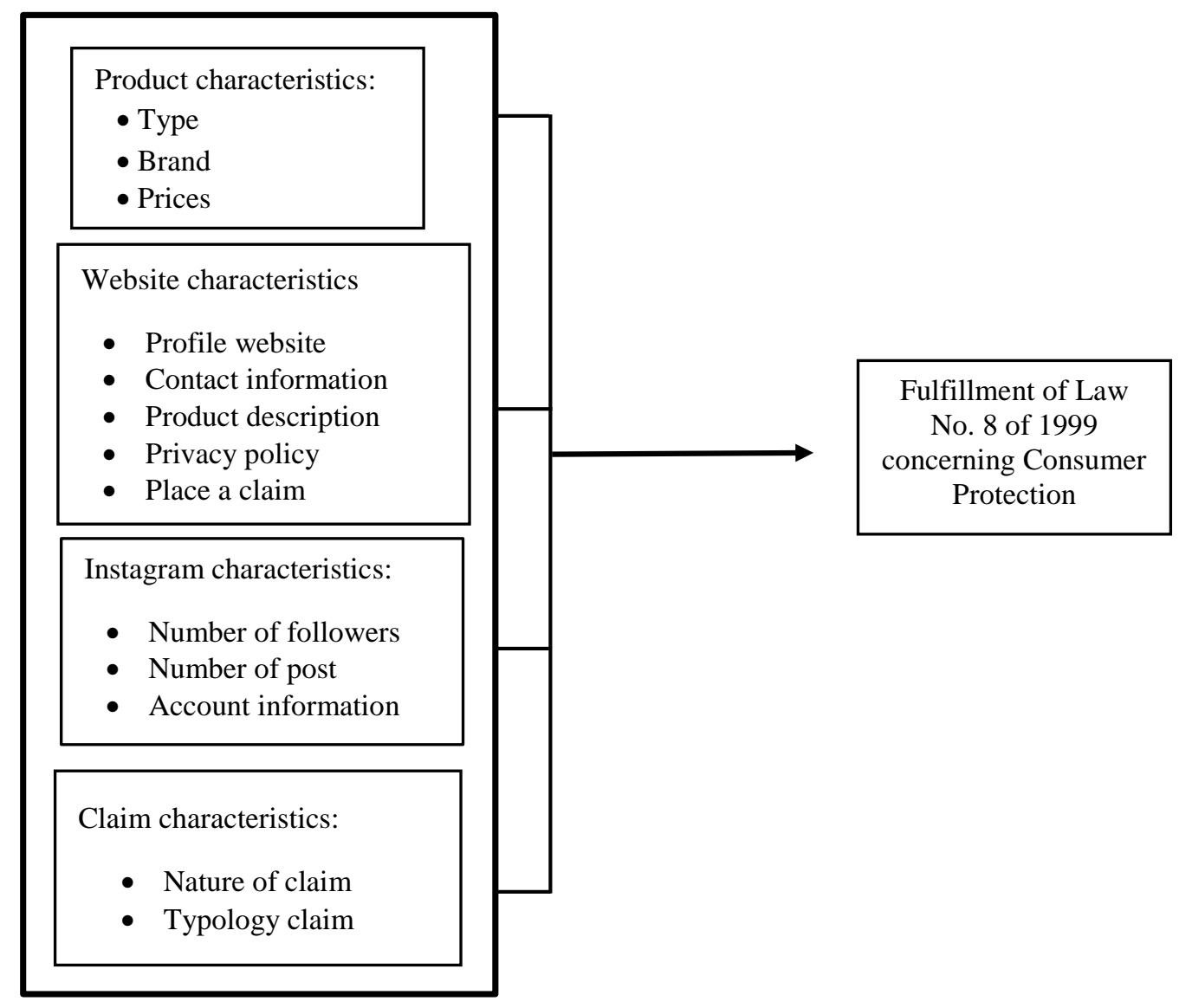

Figure 1 Conceptual Framework 


\section{Methods}

\section{Participants}

The research design used an exploratory and quantitative-qualitative design with content analysis. The data collection were conducted in February-March 2021. The population of this research is an online shop that sells organic food products. Samples of this research are 50 websites and 50 Instagram accounts that sell organic food products. The technique used in sampling is purposive sampling, i.e., samples are selected based on certain predetermined criteria such as websites in Indonesia that send their products directly to consumers and Instagram accounts that are still active and locations in Indonesia. Website searches are done through Google.com, and Instagram account searches is searched with organic food and organic food.

\section{Measurement}

This study observed several variables: product characteristics, website characteristics, Instagram characteristics, and claims characteristics. Product characteristics variables include the type of food, food brand, and price. Variables of website characteristics include website profile, contact information, product information, privacy policy, and claim location. Characteristics of an Instagram account include the number of followers, number of uploads, the layout of claims, and contact information. Variables of claim characteristics include the content of claims, nature of claims, and typology of claims. Samples are taken based on websites that sell organic food products that send their products directly to consumers and online stores on Instagram that sell organic food. Website searches are carried out on the Google.com search engine by entering the keyword "organic food website" then the top website is selected with the criteria of a company website that sends its products directly to consumers and sells various types of products.

In contrast, Instagram account searches are carried out with the keyword "organic food". Then the top Instagram store account that appears is selected, the account is from Indonesia, and the account is still active to upload products. The data that has been collected is then processed using SPSS and analyzed using the Nvivo 12 program.

\section{Analysis}

The data obtained are quantitative and qualitative. Quantitative data were analyzed and interpreted descriptively using Microsoft Excel and Statistical Package for Social Science (SPSS) 25.0 using cross-tabulation and chi-square test. The chi-square test was used to see the relationship between the number of followers and the number of uploads on Instagram. Cross tabulation is used to view the types of claims by claim category. Qualitative data were analyzed using Nvivo 12 Plus Software. Nvivo software is used to see the word frequency tool's distribution on the website profile and fill in the claims, and then the top ten and five keywords are selected. In addition, the data were also analyzed based on compliance with the Consumer Protection Law Number 8 of 1999. 


\section{Findings}

\section{Product Characteristics}

Table 1 shows organic food products sold on websites and Instagram. Each website or Instagram store sells more than one product. Therefore the total is not equal to 100. Nuts and seeds are the type of food sold the most, while the type of food sold the least is oil.

The 19 stores do not list prices. Based on the overall analysis, the price range for organic food on the website is mostly in the range Rp 1- Rp 200000 as many as 33 stores. Brands sold on every website and Instagram vary. Each store sells one or more brands. The most sold organic food brands are Lingkar Organic with 30 stores and Ladang Lima brand with 25 stores. However, there are six stores that do not list the brands they sell.

Tabel 1 Distribution of types of organic food products sold on websites and Instagram

\begin{tabular}{lr}
\hline Type of product sold & Total (n) \\
\hline Oil & 11 \\
Fruit and vegetables & 41 \\
Seeds & 88 \\
Sugar include honey & 34 \\
Spices & 53 \\
Snack & 34 \\
Instant food & 36 \\
Rice & 49 \\
\hline
\end{tabular}

\section{Website Characteristics}

Profile Website. Table 2 is an analysis of the frequency distribution of words on the website profile. The content analysis of the website profile using Nvivo 12 Plus is used to find the distribution of word usage. The process of using Nvivo, which is carried out with stopword removal, is the process of removing words that are considered not to contribute, such as because, for, in, so, and so on. For example, the word organic is the word that appears most often on the website profile 57 times.

Table 2 Analysis of word frequency distribution on the website profile

\begin{tabular}{lrrr}
\hline Word & Length & Count & \% \\
\hline Organic & 7 & 57 & 2.34 \\
Agriculture & 9 & 14 & 0.57 \\
Fresh & 5 & 12 & 0.49 \\
Offer & 10 & 8 & 0.33 \\
Quality & 8 & 7 & 0.29 \\
\hline
\end{tabular}

The word agriculture appears as many as 14. Usually, the word agriculture is followed by organic sentences such as coming from organic agriculture. The word "fresh" appears 12 times. The word "offer" appears eight times, and some websites write the word offering organic products to provide information about what the website offers. The word "quality" appears seven times, and several websites say the product quality is good on the website profile to attract consumers to buy. 


\section{Website Information}

The information shows that $88 \%$ of websites display an explanation of their brief profile. There is $98 \%$ of websites that display contact information such as Whatsapp, line, and email. In addition, the payment information shows that $40 \%$ of websites display directly on the website's home page what payment information can be used. There is $72 \%$ of websites that provide complete product descriptions, and $30 \%$ of websites that display privacy policy information.

\section{Instagram Characteristics}

Table 3 shows that Instagram stores with less than 1000 followers (38\%) have the most posts with less than 100 posts. Meanwhile, stores with 5001 to 10000 followers $(10 \%)$ have the most posts from 501 to 1000 . The chi-square test obtained a p-value of 0.000 , and this indicates a significant positive relationship between the number of followers and the number of posts. That is, the more the number of followers, the more the number of posts.

Table 3 Distribution of organic shop accounts by number of followers and number of uploads

\begin{tabular}{|c|c|c|c|c|c|}
\hline \multirow{2}{*}{ Number of Followers } & \multicolumn{4}{|c|}{ Number of posts } & \multirow{2}{*}{$\begin{array}{l}\text { Total } \\
(\%)\end{array}$} \\
\hline & $\begin{array}{r}<100 \\
(\%) \\
\end{array}$ & $\begin{array}{r}101-500 \\
(\%) \\
\end{array}$ & $\begin{array}{r}501-1000 \\
(\%) \\
\end{array}$ & $\begin{array}{r}>1000 \\
(\%) \\
\end{array}$ & \\
\hline$<1000$ & 22.0 & 12.0 & 2.0 & 2.0 & 38.0 \\
\hline $1001-5000$ & 0.0 & 16.0 & 6.0 & 6.0 & 28.0 \\
\hline 5001-10000 & 2.0 & 2.0 & 6.0 & 0.0 & 10.0 \\
\hline$>10000$ & 0.0 & 2.0 & 4.0 & 18.0 & 24.0 \\
\hline Total & 24.0 & 32.0 & 18.0 & 26.0 & 100.0 \\
\hline Pearson Chi-square & & 000 (Asyr & Significanc & ided)) & \\
\hline
\end{tabular}

\section{Account Information}

The analysis results show that the Instagram store account has a story summary (highlights) (88\%). Summary stories (highlights) can provide information such as how to order, testimonials, reviews of some goods, and other information for consumers. In addition, Instagram store accounts list their contacts $(96 \%)$ and those that do not list contacts $(4 \%)$. 


\section{Characteristic Claim}

Nature of Claim. Table 4 shows that online stores on websites and Instagram use subjective claims of $56 \%$. One of the subjective claims, such as "diet food, healthy, natural, cheap", is difficult to justify because it is only a statement from the seller.

Table 4 Distribution of website and instagram stores based on the nature of claims

\begin{tabular}{lrrl}
\hline Nature of claim & Total (n) & $\%$ & Description \\
\hline Objective & 40 & 40 & $\begin{array}{l}\text { Certified organic by USDA and EU Organic, } \\
\text { certified by MUI HALAL, Processed in production } \\
\text { facilities that have been certified by the ISO } \\
\text { Subjective }\end{array}$ \\
& 56 & $56 \begin{array}{l}\text { We use the best quality natural and organic } \\
\text { ingredients }\end{array}$ \\
Irrational & 4 & 4 & Find many benefits in every drop. \\
Two meanings & 0 & 0 & \\
\hline Total & 100 & 100 &
\end{tabular}

It is the same with the statement "we use the best quality natural and organic ingredients to make our products", but the seller does not include further information about the processing process or about the ingredients.

Table 5 shows an analysis of the word frequency distribution on the content of claims on the website and Instagram using the Nvivo 12 Plus software to find the distribution of word usage. There are five words with the most occurrences, so that the total is not $100 \%$. The word organic is the word that appears the most in the claims. The word healthy appears 22 times, and business actors use the word healthy to claim that eating organic food makes them healthier because they are free from harmful chemicals. The word preservative appears 12 times, and the intended preservative is free from preservatives. The word natural appears 11 times, and the word pesticide occurs nine times.

Table 5 Analysis of word frequency distribution in the content of claims

\begin{tabular}{lrrr}
\hline Word & Length & Count & \% \\
\hline Organic & 7 & 55 & 3.46 \\
Health & 5 & 27 & 1.70 \\
Preservative & 8 & 12 & 0.75 \\
Natural & 5 & 11 & 0.69 \\
Pesticide & 9 & 9 & 0.57 \\
\hline
\end{tabular}

Claim Typology. Table 6 shows that $47 \%$ of online stores, both websites and Instagram, are in the non-misleading category. Meanwhile, 53\% belong to the category of claims that are misleading or deceptive, such as ambiguous, which makes consumers not get their rights because they do not explain in detail the information on the claims submitted by $52 \%$. Meanwhile, based on the types of claims, most claims are based on product orientation by $68 \%$, combination claims by $15 \%$, process orientation by $7 \%$, and imaging orientation and environmental fact claims by $5 \%$. 
Table 6 Distribution of website and Instagram stores by type of claim and category of misleading/deceptive claims

\begin{tabular}{|c|c|c|c|c|c|c|}
\hline \multirow[t]{2}{*}{ Claim Type } & \multicolumn{4}{|c|}{ Categories Mislead/Deceptive } & \multirow{2}{*}{$\begin{array}{c}\text { Not } \\
\text { Misleading } \\
(\%)\end{array}$} & \multirow{2}{*}{$\begin{array}{c}\text { Total } \\
(\%)\end{array}$} \\
\hline & $\begin{array}{c}\text { Ambiguous } \\
(\%)\end{array}$ & $\begin{array}{c}\text { Negligence } \\
(\%)\end{array}$ & $\begin{array}{c}\text { Lie/ } \\
\text { cheat } \\
(\%)\end{array}$ & $\begin{array}{c}\text { Combination } \\
(\%)\end{array}$ & & \\
\hline $\begin{array}{l}\text { Product } \\
\text { orientation }\end{array}$ & 37 & 1 & 0 & 0 & 30 & 68 \\
\hline $\begin{array}{l}\text { Proceed } \\
\text { orientation }\end{array}$ & 2 & 0 & 0 & 0 & 5 & 7 \\
\hline $\begin{array}{l}\text { Image } \\
\text { Orientation }\end{array}$ & 5 & 0 & 0 & 0 & 0 & 5 \\
\hline $\begin{array}{l}\text { Environmental } \\
\text { Facts }\end{array}$ & 1 & 0 & 0 & 0 & 4 & 5 \\
\hline Combination & 7 & 0 & 0 & 0 & 8 & 15 \\
\hline Total & 52 & 1 & 0 & 0 & 47 & 100 \\
\hline
\end{tabular}

\section{Fulfilment of Law No. 8 of 1999 concerning Consumer Protection}

Based on website analysis, $22 \%$ of online stores violate Article 8 Paragraph 1 of the UUPK, namely by not including further information about the food products being sold (name of goods, size, weight/content, and net or net). Some business actors also sell products that do not use labels but claim halal and organic. The analysis results also show that $20 \%$ of online shops violate article 9 of the Consumer Protection Act by using words such as safe, harmless, natural, natural, and indirectly demeaning other food products.

Table 7 Distribution of website stores and Instagram based on compliance with the Consumer Behaviour Act

\begin{tabular}{|c|c|c|c|c|}
\hline \multirow[t]{2}{*}{ Law Fulfillment } & \multicolumn{2}{|c|}{ Offense Category } & \multirow{2}{*}{$\begin{array}{r}\text { Total } \\
(\%)\end{array}$} & \multirow[t]{2}{*}{ Description } \\
\hline & $\begin{array}{c}\text { Violation } \\
(\%)\end{array}$ & $\begin{array}{c}\text { Not } \\
\text { Violation } \\
(\%)\end{array}$ & & \\
\hline UUPK Pasal 8 & 22 & 78 & 100 & $\begin{array}{l}\text { Does not include information in } \\
\text { Indonesian. Does not include } \\
\text { further information related to food } \\
\text { products sold, such as an } \\
\text { explanation containing the name } \\
\text { of the item, size, net or net } \\
\text { weight/content and content. }\end{array}$ \\
\hline UUPK Pasal 9 & 20 & 80 & 100 & $\begin{array}{l}\text { Using words like safe, harmless, } \\
\text { natural, natural, and indirectly } \\
\text { demeaning other food products }\end{array}$ \\
\hline
\end{tabular}




\section{Discussion}

The results of the analysis on 100 online stores on the website and Instagram are categorized into eight categories of types of food, namely: (1) fat, oil, oil emulsion; (2) fruits and vegetables; (3) nuts and seeds; (4) sugar and sweeteners including honey; (5) salt, spices/seasonings, sauces; (6) light meals; (7) packaged food (ready-to-eat); (8) rice. Each store sells various product categories. The results show that the types of products that are sold the most are nuts and seeds. The price range for organic food that is most widely sold is Rp. 1 to Rp. 200.000 , and the most widely sold brand is the organic circle.

Most of the website stores analyzed had brief information about the website profile listed on the website page, contact information that could be contacted, and product descriptions. While on payment information, $60 \%$ of websites do not list in advance what payment method can be used, so buyers must order the product in advance to know what payment method is used. In addition, for information regarding the privacy policy, there are still few websites that display it.

The use of Nvivo is done with stopword removal, which is the process of removing words that are considered not to have an important contribution such as because, for, in, so, and so on. The word "organic" is the word that most often appears on the website profile, and business actors write the word organic to provide information that their shop sells organic products. Product and website characteristics are carried out because according to the research of Vega, Torres, Murgado, \& Parras (2014).

Store characteristics on Instagram are seen in this study. This is different from previous research, which looks at the relationship between the number of likes on an upload and the number of followers (followers), resulting in a significant relationship. In this study, we want to see a new relationship between the number of followers (followers) and the number of uploads. There is a positive relationship, namely a significant difference between the number of followers and the number of uploads with a focus on the Instagram application. This shows that the more followers, the more uploads to the account. According to Sarah's (2020), on Instagram, business actors must post informative and clear content to get high followers. Store information such as contact information and highlights are analyzed in this study. The most accounts already display contact information that can be contacted for orders on their profile views, such as phone numbers, emails, Whatsapp, and others. The majority of accounts also feature highlights to provide information to consumers. This highlight usually contains product prices, other consumer testimonials, product information sold, and any information that needs to be provided.

The characteristics of claims consist of the nature of claims (Sumarwan, 2011), subjective, objective, irrational, two meanings and typology of claims, namely the type of claim and the category of claims (Carlson, Grove \& Kangun, 1993). The analysis results show that online stores on websites and Instagram mostly use subjective claims of $56 \%$. Subjective claims are subjective information, difficult to prove true because they are statements from business actors only, and difficult to measure objectively (Sumarwan, 2011). The analysis also shows that most of the claims belong to the ambiguous claim category, with the types of claims being product orientation and process orientation. Product orientation claims are claims that are oriented towards product attributes or specifications owned by the product. Meanwhile, process 
orientation claims are claims related to internal technology, production techniques, and disposal methods. For example, organic food claims about taste include misleading claims, and taste cannot be objective because it is difficult to justify claims that a product tastes better than other products (Cagalj et al., 2016).

The word frequency distribution analysis is also used on claims content both on the website and Instagram. The frequency analysis of the content of claims is carried out using the Nvivo 12 Plus software to find the distribution of word usage. The analysis results show ten keywords, namely organic, healthy, preservative, natural, pesticide, halal, content, chemical, certification, and environment. Claims related to organic food are the most popular health claims. Health claims are the most communicated by consumers because consumers buy organic food to improve their health. Therefore, many business actors use "healthy" claims on organic food products (Pilar, Stanislavská \& Kvasnicka, 2021). The most common claims used in selling organic food are environmental claims, taste claims, and health claims. Nutrition and health claims are seen to promote aspects of healthy eating (Steinhauser, Janssen \& Hamm, 2019).

This study uses Law Number 8 of 1999 concerning Consumer Protection Articles 8 and 9 . As much $22 \%$ of online stores both on websites and Instagram violate Article 8 Paragraph 1 by not including further information related to food products sold, such as an explanation containing the item name, size, net or net weight/content and content. Some business actors also sell products that do not use labels but claim halal and organic. In contrast, business actors who have obtained organic certification need to install organic labelling or logos. This labelling contains the identity of a product (Wibowo \& Husnain, 2015). The analysis results also show that $20 \%$ of online shops violate article 9 of the Consumer Protection Act by using words such as safe, harmless, natural, natural, $100 \%$ pure and indirectly demeaning other food products. When transacting between consumers and business actors online, the consumers who often experience losses are because consumers depend on advertisements or information displayed by business actors. If business actors display incorrect information, consumers will feel disadvantaged (Laila, 2017).

Based on research, there are still organic food online stores that do not display complete information, and the claims provided are misleading. The number of subjective and misleading claims makes consumers have to be careful. Subjective claims are usually only the seller's statement not supported by evidence. Consumers are expected not to easily believe in claims that are not necessarily true, especially in organic food products. Before deciding to buy organic food, consumers should seek information first. If they do not pay attention to the information correctly, it will be detrimental to the consumers themselves. The managerial implication of this research is to increase consumer's understanding of organic food and its claims and understanding of consumer behaviour legislation for consumer welfare, such as article 8 and article 9 of UUPK No. 8 of 1999. Consumers must be smart and critical in receiving information. We recommend that you review the information on Instagram or the business actor's website, such as organic labels and organic certifications or objective claims that can be proven. In addition to consumers, business actors who display advertisements or product claims on online platforms must follow laws and regulations and ethics so that the advertisements still have good morality for consumers.

Every research has its shortcomings and limitations. The limitation of this research is that it is difficult to find literacy about similar content analysis. Apart from the different media and aspects studied, content analysis techniques are still rarely used. 
In the content analysis technique, we cannot see the relationship between the analyzed variables unless it is connected with other research methods.

\section{Conclusion and Recommendation}

\section{Conclusion}

The results of the content analysis of product characteristics, the category of food sold the most are nuts and seeds, the price range of organic food sold is $\mathrm{Rp} 1$ to $\mathrm{Rp} 200$ 000 , and the brand that is sold the most is the organic circle. In addition, the most expensive categories are rice and sugar or sweeteners, including honey. There are various brands found, but the most expensive brands are organic circle and uray honey. The characteristics of the website that were analyzed more than some websites already displayed complete information. However, for payment information and privacy policies, many websites still do not display it. Most of the claims on the website are on the website display and product descriptions. For the characteristics of Instagram accounts, the chi-square test shows a significant positive relationship between the number of followers and the number of uploads. More than a few Instagram stores already display information such as story highlights and contact information. Most of the claims on Instagram are on Instagram profiles, product images, and product descriptions.

The results of the analysis of the characteristics of claims, most of the claims used in organic food are product-oriented subjective claims. Some online stores also display claims under the category of misleading or deceptive claims, such as ambiguous. The top five words found in the content of the claim are organic, healthy, preservative, natural, and pesticide. As much 20\% of online shops violate Article 8 Paragraph 1 by not including further information regarding the food products being sold, such as an explanation containing the item's name, size, net or net weight/content, and content. There is also $20 \%$ of online shops that violate Article 9 of the Consumer Protection Act by using words such as safe, harmless, natural, natural, and indirectly demeaning other food products.

\section{Recommendation}

Consumers must be careful because there are still ambiguous claims such as unclear meaning and misleading using erroneous information. Ambiguous and misleading claims are very detrimental to consumers. In addition, consumers must pay attention to the product information provided by business actors regarding the content or composition of the organic food, preferably if the business actor displays an organic certificate issued by the relevant institution. The government and related institutions should supervise organic food online business actors in advertising their products, which still give subjective and irrational claims. Suggestions for future research are to examine more characteristics and samples of online stores. For further research, it is possible to combine research methods, not only content analysis, to get the relationship between the variables analyzed. 


\section{References}

Ahmad, J. (2018). Content analysis research design. Research Gate, 5, 1-20. Doi:10.13140/RG.2.2.12201.08804

Burton, S., Lichtenstein, D., Netemeyer, R., \& Garretson, J. (1998). A scale for measuring attitude toward private label products and an examination of its psychological and behavioral correlates. Journal of the Academy of Marketing Science, 26(4), 293-306. Doi:10.1177/0092070398264003

Cagalj, M., Haas, R., \& Morawetz, U. B. (2016). Effects of quality claims on willingness to pay for organic food: Evidence from experimental auctions in Croatia. Br. Food J, 118(9), 2218-2233. Doi:10.1108/BFJ-11-2015-0453.

Carlson, L., Grove, S. J., \& Kangun, N. (1993). A content analysis of environmental advertising claims: A matrix method approach les carlson. J. Advert, 22(3), 2739. Doi: 10.1080/00913367.1993.10673409.

Eriyanto. (2011). Content analysis: Introduction to Methodology for Research in Communication Studies and other social sciences. Jakarta(ID): Prenadamedia

Fauzi, M. I., \& Yuliawati, Y. (2020). Consumer behavior in buying organic vegetables PO Merbabu organic vegetables (case study Yogyakarta). Journal of Agricultural and Agribusiness Economics, 4(4), 752-762. Doi: https://doi.org/10.21776/ub.jepa.2020.004.04.05

Fitria, E. M. (2015). The impact of the online shop on Instagram in changing the consumptive lifestyle of shopaholic women in Samarinda. Journal of Communication Science, 1(3), 117-128

Hao, N., Wang, H. H., \& Zhou, Q. (2020). The impact of online grocery shopping on stockpile behaviour in Covid-19. China Agricultural Economic Review, 12(3), 459-470. Doi: 10.1108/CAER-04-2020-0064.

Ichsan, M., Jumhur, H. M., Hum, M., \& Dharmoputra, I. S. (2018). The influence of consumer online ratings and reviews on consumer buying interest in the Tokopedia marketplace in the DKI Jakarta area. e-Proceddings of Management, 5(2),1828-1835. ISSN: 2355-9357.

Institute, O., Alifa, Y., \& Kombas. (2019). Indonesia Organic Agriculture Statistics 2019. Volume ke-53.

Kahl, J., Van Der Burgt, G. J., Kusche, D., Bügel, S., Busscher, N., Hallmann, E., Kretzschmar, U., Ploeger, A., Rembialkowska, E., \& Huber, M. (2010). Organic food claims in Europe. Food Technol, 64(3), 38-46.

Kertamukti, R., Ilmu, D., Uin, K., Kalijaga, S. (2015). Instagram and image formation (a qualitative study of visual communication in the formation of the personal character of the @basukibtp Instagram account). Journal of Prophetic Communication, 8(01), 57-66. E-ISSN: 2549-0168.

Krippendorff, K. (2018). Content analysis: An introduction to its methodology. Sage publications.

Kurniawan, G. (2020). Consumer behavior in buying organic rice products through ecommerce. Surabaya(ID): Mitra Abisatya.

Lahteenmaki, L. (2013). Claiming health in food products. Food Quality and Preferences, 27(2), 196-201. Doi:10.1016/j.foodqual.2012.03.006

Laila, K. (2017). Legal Protection Against Consumers for Advertising Violating Advertising Procedures. J. Cakrawala Huk, 8(1), 64-74. Doi: https://doi.org/10.26905/idjch.v8i1.1732 
Martono, N. (2011). Quantitative Research Methods: Content Analysis and Secondary Data Analysis. Jakarta(ID): RajaGrafindo Persada

Mayrowani, H. (2012). Organic Agriculture Development in Indonesia. Agro-Economic Research Forum, 30(2), 91-108.

Minsiter of Agriculture Republic Indonesia. (2013). Minister of Agriculture Regulation concerning Organic Agriculture System Number 64/Permentan/Ot.140/5/2013.

National Agency of Drug and Food Control. (2017). Food and Drug Supervisory Agency of the Republic of Indonesia Number 1 of 2017 concerning Control of Organic Processed Food.

Novita, N. (2017). The role of organic certification for small-scale farmers with local market reach (empirical study on organic small-scale farmers in Bogor, West Java). Journal of Business \& Applied Management, 8(2), 1-20. E-ISSN: 26212752.

Pilar, L., Stanislavská, L. K., Kvasnicka, R. (2021). Healthy food on the twitter social network: vegan, homemade, and organic food. International Journal of Environmental Research and Public Health, 18(7), 3815. Doi: 10.3390/ijerph18073815

Pudjiarti E., Nurlaela, D., Sulistyani, W. (2019). Website-based rice sales information system. Indones. J. Softw. Eng, 5(1), 62-74. Doi: 10.31294/ijse.v5i1.5865.

Qi, X., Yu, H., \& Ploeger, A. (2020). Exploring influential factors including COVID-19 on green food purchase intentions and the intention-behaviour gap: A qualitative study among consumers in a Chinese context. Int. J. Environ. Res. Public Health, 17(19), 1-22. Doi: 10.3390/ijerph17197106.

Steinhauser, J., Janssen, M., Hamm, U. (2019). Consumers' purchase decisions for products with nutrition and health claims: what role do product category and gaze duration on claims play?. Appetite, 141, 104337. Doi: 10.1016/j.appet.2019.104337.

Sumarwan, U. (2011). Consumer Behavior: Theory and Its Application in Marketing. Bogor(ID): Ghalia Indonesia

Sumarwan, U., Noviandi, A., \& Kirbrandoko, K. (2013). An analysis of purchasing decisions, perceptions and consumer attitudes toward organic rice in Jabodetabek. J. FOOD, 22(2), 87-104. Doi: 10.33964/JP.V22I2.81.

Vega, M., Torres, F. J., Murgado, E. M., \& Parras, M. (2014). Organic as a heuristic cue: What Spanish consumers mean by organic foods. Psychology \& Marketing, 31(5), 349-359. Doi: https://doi.org/10.1002/mar.20699

Waskito, D., Ananto, M., \& Reza, A. (2014). Consumer perception of organic food in Yogyakarta. Pelita - J. Researchers. Mhs. UNY, 9(1), 36-48

Wibowo, H., \& Husnain. (2015). In book: Organic Farming Systems Support Sustainable Land Productivity (pp.153-169). Edition: 1, Chapter: 08. Publisher: IAARD Press

Wijaya, T. (2017). The value of human natural orientation and organic knowledge as determinants of buying behavior for organic food. J. Business Strategy, 21(2), 161-180. Doi:10.20885/jsb.vol21.iss2.art5

Windani, I., Kikik, D., \& Awaliyah, S. (2020). Consumer preferences for organic food in Indonesia. Proceedings of the 3rd Integrated Livestock Agriculture National Seminar ISBN : 978-602-60782-2-3 [622] 
Wulandari, S. D., \& Husna, J. (2016). Analysis of the quality of the Instagram account information online shop @dresscodemg Semarang. Journal of Library Science, $5(3)$. 